DOI: https://doi.org/10.31933/jimt.v2i6

Received: 7 April 2021, Revised: 7 Mei 2021, Publish: 20 Juli 2021

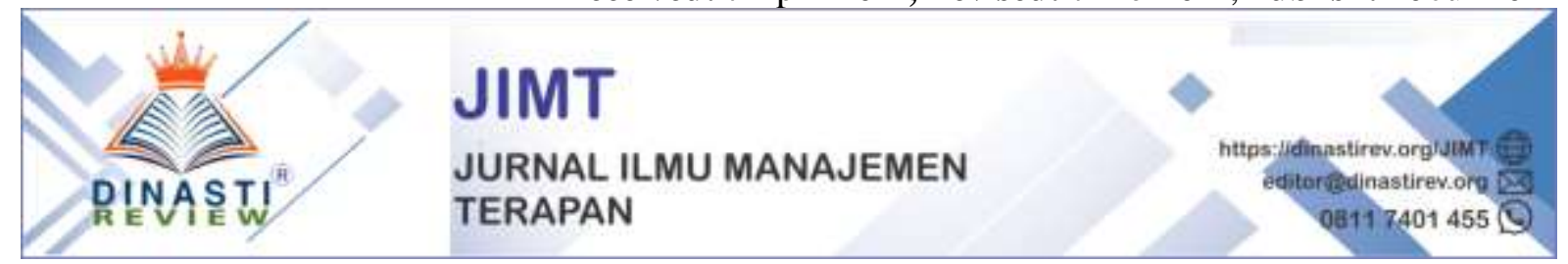

\title{
HUBUNGAN ANTARA PENDIDIKAN, JAM KERJA, DAN USIA TERHADAP HUKUM TENAGA KERJA
}

\author{
Windi Suarni ${ }^{1}$, Annisa Nurul Audri ${ }^{2}$ \\ 1) Fakultas Ekonomi \& Bisnis, Universitas Mercu Buana Jakarta, email: \\ windisuarn8@gmail.com \\ ${ }^{2}$ Fakultas Ekonomi \& Bisnis, Universitas Mercu Buana Jakarta, email: \\ annisaaudri@gmail.com
}

Corresponding Author: Windi Suarni ${ }^{1}$

\begin{abstract}
Abstrak : Penelitian ini bertujuan untuk melihat bagaimana hubungan Pendidikan, jam kerja ,dan usia pada hukum tenaga kerja.. Metode penulisan artikel ilmiah ini adalah dengan metode kualitatif dan studi jurnal yang relevan serta Mengkaji Buku-buku sesuai dengan teori yang di bahas khusunya pada hukum tenaga kerja. Disamping itu menganalisis artikel-artikel ilmiah yang bereputasi dan juga artikel ilmiah dari jurnal yang belum bereputasi. Untuk menyelesaikan pokok permasalahan. Dari hasil penelitian ini dapat desimpulkan bahwa 1) Pendidikan Memiliki Hubungan terhadap Hukum Tenaga Kerja; 2) Jam Kerja Memiliki Hubungan terhadap Hukum Tenaga Kerja; dan 3) Usia memiliki hubungan terhadap Hukum Tenaga Kerja.
\end{abstract}

Kata Kunci : Hukum Tenaga Kerja, Pendidikan, Jam Kerja , dan Usia

\section{PENDAHULUAN}

\section{Latar Belakang Masalah.}

Pada konsiderans huruf d Undang-Undang No. 13 Tahun 2003 tentang Ketenagakerjaan menyatakan bahwa:"Perlindungan terhadap tenaga kerja dimaksudkan untuk menjamin hakhak dasar pekerja/buruh dan menjamin kesamaan kesempatan serta perlakuan tanpa diskriminasi atas dasar apapun untuk mewujudkan kesejahteraan pekerja/buruh dan keluarganya dengan tetap memperhatikan perkembangan kemajuan dunia usaha”.

Hal tersebut dipertegas pada Pasal 6 Undang-Undang No. 13 Tahun 2003 tentang Ketenagakerjaan yang menyatakan: "setiap pekerja/buruh berhak memperoleh perlakuan yang sama tanpa diskriminasi dari pengusaha”. Maka setiap pekerja berhak memperoleh perlakuan yang sama tanpa perbedaan dari pengusaha, tinggal bagaimana pengusaha dalam merealisasikannya . Baik dari mulai pekerja itu diterima sebagai pekerja sampai dengan penempatan dan pada masa pekerja melaksanakan pekerjaan di perusahaan.

Menurut Undang-UndangNomor 20 Tahun 2003, pendidikan adalah usaha sadar dan terencana untuk mewujudkan suasana belajar dan proses pembelajaran agar peserta didik secara aktif mengembangkan potensi dirinya untuk memiliki kekuatan spiritual 
keagamaan,pengendalian diri, kepribadian, kecerdasan, akhlak mulia, serta ketrampilan yang diperlukan dirinya, masyarakat, Seorang pekerja yang berpendidikan dan memiliki keterampilan akan lebih mudah untuk mendapatkan pekerjaan di suatu perusahaan.

Undang-Undang No.13 tahun 2003 tentang Ketenagakerjaan, khususnya pasal 77 sampai dengan pasal 85. Pasal 77 ayat 1, Undang-Undang No.13/2003 mewajibkan setiap pengusaha untuk melaksanakan ketentuan jam kerja. Suatu perusahaan sudah menetapkan jam kerja seorang pekerja sesuai dengan ketentuan hukum yang berlaku yaitu selama 1 hari 78 jam dan jika pekerja berkerja melebih jam tersebut maka dia dianggap lembur.

Menurut Depnakertrans Tahun 2006 pengertian tenaga kerja ada 2 yaitu, Setiap orang yang mampu melakukan pekerjaan guna menghasilkan barang dan jasa baik untuk memenuhi kebutuhan sendiri maupun masyarakat. Dan Setiap orang laki -laki atau wanita yang berumur 15 tahun ke atas yang sedang dalam dan atau akan melakukan pekerjaan baik di dalam maupun di luar hubungan kerja guna menghasilkan barang atau jasa untuk memenuhi kebutuhan masyarakat. Usia memiliki kaitan dengan hukum ternaga kerja dan hukum Pendidikan karna pada hukum seorang yang memiliki latar belakang Pendidikan yang tinggi dan ketrampilan, pekerja tersebut dapat dengan mudah mendapatkan pekerjaan dan pengaruh usia pada hukum tersebut yang mana seorang anak dibawah 15 tahun tidak boleh bekerja karna memang belum waktunya. Karna pada dasarnya ada yang berusia dibawah 15 tahun belum memiliki sikap kedewasaan yang sempurna, oleh karna itu pendidik, dan usia saling berkaitan pada hukum tenaga kerja yang berlaku. Artikel ini membahas hubungan Pendidikan, jam kerja, dan usia terhadap hukum tenaga kerja, suatu studi literatur Hukum Keternagakerjaan

\section{Rumusan Masalah.}

1. Apakah Hubungan Pendidikan memiliki hubungan dan berpengaruh terhadap Hukum Tenaga Kerja?

2. Apakah Hubungan Pengalaman Kerja memiliki hubungan dan berpengaruh terhadap Hukum Tenaga Keja ?

3. Apakah Hubungan Usia memiliki hubungan dan berpengaruh terhadap hukum tenaga kerja?

\section{KAJIAN TEORI \\ Hukum Keternagakerjaan}

\section{Undang-Undang Keternagakerjaan}

Hukum ketenagakerjaan di Indonesia diatur di dalam UU No. 13 Tahun 2003 tentang Ketenagakerjaan. Hukum ketenagakerjaan mengatur tentang segala hal yang berhubungan dengan tenaga kerja pada waktu sebelum, selama, dan sesudah kerja. Tujuan dari dibentuknya hukum ketenagakerjaan adalah untuk :

$>$ memberdayakan dan mendayagunakan tenaga kerja secara optimal dan manusiawi;

mewujudkan pemerataan kesempatan kerja dan penyediaan tenaga kerja yang sesuai dengan kebutuhan pembangunan nasional dan daerah;

memberikan perlindungan kepada tenaga kerja dalam mewujudkan kesejahteraan; dan 
$>$ meningkatkan kesejahteraan tenaga kerja dan keluarganya

Selain itu, hukum ketenagakerjaan juga mengatur hubungan antara tenaga kerja dengan pengusaha. Hubungan kerja terjadi karena adanya perjanjian kerja antara pengusaha dan pekerja/buruh. Hubungan kerja terdiri dari dua macam yaitu hubungan kerja berdasarkan Perjanjian Kerja Waktu Tertentu (PKWT) dan hubungan kerja berdasarkan Perjanjian Kerja Waktu Tidak Tertentu (PKWTT). Perjanjian kerja yang dibuat tersebut dapat dilakukan secara tertulis atau lisan. Perjanjian kerja yang dipersyaratkan secara tertulis harus dilaksanakan sesuai dengan peraturan perundang undangan yang berlaku. Mengenai hubungan kerja tersebut diatur di Bab IX Pasal 5066 UU No. 13 Tahun 2003 tentang Ketenagakerjaan. Perjanjian kerja yang dibentuk antara pengusaha dan pekerja/buruh haruslah berlandaskan dan sesuai dengan substansi dari UU No. 13 Tahun 2003 tentang Ketenagakerjaan dan peraturan hukum lainnya yang terkait.

Di dalam menjalankan aktivitas perusahaan, pengusaha mempunyai kewajiban untuk memenuhi hak dari setiap pekerja. Hak pekerja tersebut diantaranya yaitu hak untuk mendapatkan perlakuan yang sama tanpa diskriminasi atas dasar apapun, hak untuk mengembangkan kompetensi kerja, hak untuk beribadah menurut agama dan kepercayaannya, hak untuk mendapatkan upah atau penghasilan yang sesuai dengan harkat dan martabat manusia, hak untuk mendapatkan perlindungan, kesejahteraan, kesehatan, dan keselamatan kerja.

Apabila pekerja merasa bahwa hak-haknya yang dilindungi dan diatur di dalam UU No. 13 Tahun 2003 tentang Ketenagakerjaan tersebut merasa tidak terpenuhi dan diabaikan oleh pengusaha maka hal tersebut akan dapat menyebabkan perselisihanperselisihan tertentu antara pengusaha dan pekerja. Jika perselisihan itu terjadi, maka peraturan hukum di Indonesia telah mengaturnya di dalam UU No. 2 Tahun 2004 tentang Penyelesaian Perselisihan Hubungan Industrial. Perselisihan Hubungan Industrial adalah perbedaan pendapat yang mengakibatkan pertentangan antara pengusaha atau gabungan pengusaha dengan pekerja/buruh atau serikat pekerja/serikat buruh karena adanya perselisihan mengenai hak, perselisihan kepentingan, perselisihan pemutusan hubungan kerja dan perselisihan antar serikat pekerja/serikat buruh dalam satu perusahaan. Setiap bentuk perselisihan tersebut memiliki cara atau prosedur tersendiri untuk menyelesaikannya baik itu melalui perundingan bipartit, mediasi, konsiliasi, arbitrase, atau diselesaikan di Pengadilan Hubungan Industrial.

\section{Peraturan-peraturan terkait Ketenagakerjaan:}

> Undang-Undang No. 13 Tahun 2003 tentang Ketenagakerjaan

$>$ Undang-Undang No. 2 Tahun 2004 tentang Penyelesaian Perselisihan Hubungan Industrial

> Undang-Undang No. 21 Tahun 2000 tentang Serikat Pekerja/Serikat Buruh

> Undang-Undang No. 40 Tahun 2004 tentang Sistem Jaminan Sosial

$>$ Undang-Undang No. 39 Tahun 200 tentang Penempatan dan Perlindungan Tenaga Kerja Indonesia di Luar Negeri

$>$ Undang-Undang No. 21 Tahun 2003 tentang Pengesahan ILO Convention No. 81 Concerning Labour Inspection in Industry and Commerce (Konvensi ILO No. 81 Mengenai Pengawasan Ketenagakerjaan dalam Industri dan Perdagangan) 
> Undang-Undang No. 1 Tahun 2000 tentang Pengesahan ILO Convention No.182 Concerning the Prohibition and Immediate Action for Elimination of the Worst Forms of Child Labour (Konvensi ILO No.182 Mengenai Pelarangan dan Tindakan Segera Penghapusan Bentuk Bentuk Pekerjaan Terburuk untuk Anak)

> Undang-Undang No. 21 Tahun 1999 tentang Pengesahan ILO Convention No. 111 concerning Discrimination in Respect of Employment and Occupation (Konvensi ILO mengenai Diskriminasi dalam Pekerjaan dan Jabatan) Undang-Undang No. 20 Tahun 1999 Pengesahan tentang ILO Convention No. 138 concerning Minimum Age for Admission to Employment (Konvensi ILO mengenai Usia Minimum untuk Diperbolehkan Bekerja)

$>$ Undang-Undang No. 19 Tahun 1999 tentang Pengesahan ILO Convention No. 105 concerning the Abolition of Forced Labour (Konvensi ILO mengenai Penghapusan Kerja Paksa)

$>$ Peraturan Pemerintah No. 46 Tahun 2015 tentang Penyelenggaraan Program Jaminan Hari Tua

$>$ Peraturan Pemerintah No. 45 Tahun 2015 tentang Penyelenggaraan Program Jaminan Pensiun

$>$ Peraturan Pemerintah No. 44 Tahun 2015 tentang Penyelenggaraan Program Jaminan Kerja Dan Jaminan Kematian

$>$ Peraturan Pemerintah No. 4 Tahun 2015 tentang Pelaksanaan Pengawasan Terhadap Penyelenggaraan Penempatan Dan Perlindungan Tenaga Kerja Indonesia Di Luar Negeri

$>$ Peraturan Presiden No. 72 Tahun 2014 tentang Penggunaan Tenaga Kerja Asing Serta Pelaksanaan Pendidikan Dan Pelatihan Tenaga Kerja Pendamping

$>$ Peraturan Presiden No. 111 Tahun 2013 tentang Perubahan Atas Peraturan Presiden Nomor 12 Tahun 2013 Tentang Jaminan Kesehatan

$>$ Peraturan Presiden No. 21 Tahun 2010 tentang Pengawasan Ketenagakerjaan

$>$ Peraturan Presiden No. 81 Tahun 2006 tentang Badan Nasional Penempatan dan Perlindungan Tenaga Kerja

> Peraturan Presiden No. 64 Tahun 2011 tentang Pemeriksaan Kesehatan dan Psikologi Calon Tenaga Kerja Indonesia

> Peraturan Presiden No. 45 Tahun 2013 tentang Koordinasi Pemulangan Tenaga Kerja Indonesia

$>$ Peraturan Presiden No.12 Tahun 2013 tentang Jaminan Kesehatan

\section{3. konsekuensi hukum yang timbul dari kesepakatan kerja}

Perjanjian kerja yang bertentangan dengan peraturan perundang-undangan mengakibatkan perjanjian tersebut batal demi hukum sehingga dianggap tidak pernah ada. Syarat sahnya perjanjian kerja diatur dalam Pasal 52 Undang-Undang No. 13 Tahun 2003 tentang Ketenagakerjaan, berbunyi:

"Pasal 52"

1) Perjanjian kerja dibuat atas dasar:

$>$ kesepakatan kedua belah pihak;

$>$ kemampuan atau kecakapan melakukan perbuatan hukum; 
$>$ adanya pekerjaan yang diperjanjikan; dan

$>$ pekerjaan yang diperjanjikan tidak bertentangan dengan ketertiban umum, kesusilaan, dan peraturan perundang-undangan yang berlaku.

2) Perjanjian kerja yang dibuat oleh para pihak yang bertentangan dengan ketentuan sebagaimana dimaksud pada ayat (1) huruf a dan b dapat dibatalkan.

3) Perjanjian kerja yang dibuat oleh para pihak yang bertentangan dengan ketentuan sebagaimana dimaksud pada ayat (1) huruf c dan d batal demi hukum."

Pasal 52 ayat (3) di atas telah jelas menyatakan perjanjian kerja yang dibuat bertentangan dengan ketertiban umum, kesusilaan, dan peraturan perundang-undangan yang berlaku mengakibatkan perjanjian kerja tersebut batal demi hukum.

Dikaitkan dengan kasus Anda, jelas perjanjian kerja yang Anda buat dengan perusahaan itu batal demi hukum. Perlu diingat, yang batal itu bisa perjanjiannya sebagai satu kesatuan atau bisa juga yang batal hanya pasal-pasal atau ketentuan dalam perjanjian yang bertentangan dengan UU saja. Batal demi hukum berarti perjanjian itu dianggap tidak pernah ada. Sehingga acuannya kembali lagi kepada apa yang sudah diatur dalam UU.

Sebagai contoh, Pasal 90 ayat (1) UU Ketenagakerjaan mengatakan pengusaha dilarang membayar upah di bawah upah minimum. Upah minimum tahun 2016 berdasarkan Peraturan Gubernur DKI Jakarta No. 230 tahun 2015 adalah Rp. 3.100.000,-. Namun dalam perjanjian kerja, ada pasal/ketentuan yang mengatur bahwa upah anda hanya 2.500.00,-.. dalam konteks ini, pasal yang mengatur upah anda 2.500.000,- tersebut jelas bertentangan dengan UU sehingga batal demi hukum, dan wajib merujuk kembali kepada ketentuan sebagaimana diatur dalam peraturan perundang-undangan yaitu Rp. 3.100.00,-

Berdasarkan dasar hukum tersebut Anda bisa menyampaikan ke perusahaan agar menyesuaikan ketentuan-ketentuan yang ada di dalam perjanjian kerja dengan UU yang berlaku sehingga hak-hak Anda sebagai karyawan tidak dilanggar. Jika tidak ada kesepakatan antara Anda (karyawan) dan pengusaha terkait hal ini, Anda bisa mengajukan gugatan ke Pengadilan Hubungan Industrial atas dasar gugatan perselisihan hak dan meminta agar perjanjian kerja tersebut disesuaikan dengan UU atau peraturan perundang-undangan yang berlaku.

Kesimpulan, perjanjian kerja yang bertentangan dengan UU berakibat perjanjian tersebut batal demi hukum sehingga dianggap tidak pernah ada.Seharusnya yang perlu diatur dalam perjanjian kerja itu adalah hal-hal yang belum diatur dalam UU. Jika sudah diatur secara tegas dalam UU, tidak diijinkan adanya penyimpangan lagi kecuali jika penyimpangan itu jelas dibolehkan oleh UU.

\section{4. mengetahui hak dan kewajiban Pekerja / Buruh dan Majikan / Pengusaha}

\section{Buruh / Pekerja}

Sebagai pemilik perusahaan, kadang Anda terlalu fokus kepada kewajiban pekerja dan apa yang harus mereka berikan kepada perusahaan. Bagi Anda, yang paling penting pekerja menerima kompensasi berupa upah sesuai jam kerja mereka. Sementara Divisi HR sebaliknya, lebih cenderung pada hak-hak pekerja daripada 'hak' perusahaan sebagai pemberi kerja. Ketimpangan antara hak dan kewajiban pekerja ini seharusnya tidak menjadi masalah, 
karena Undang-undang Nomor 13 Tahun 2003 Tentang Ketenagakerjaan sudah mengaturnya dengan selaras.:

Sementara itu, pekerja juga memiliki kewajiban, antara lain:

\begin{tabular}{|c|c|c|}
\hline Bab & $\begin{array}{l}\text { Pasal } \\
\text { (Ayat) }\end{array}$ & Bunyi \\
\hline \multirow{4}{*}{$\begin{array}{l}\text { XI } \\
\text { Hubungan } \\
\text { Industrial }\end{array}$} & $\begin{array}{l}102 \\
(2)\end{array}$ & $\begin{array}{l}\text { Dalam melaksanakan hubungan industrial, pekerja/buruh dan } \\
\text { serikat pekerja/serikat buruhnya mempunyai fungsi menjalankan } \\
\text { pekerjaan sesuai dengan kewajibannya, menjaga ketertiban demi } \\
\text { kelangsungan produksi, menyalurkan aspirasi secara demokratis, } \\
\text { mengembangkan keterampilan, dan keahliannya serta ikut } \\
\text { memajukan perusahaan dan memperjuangkan kesejahteraan } \\
\text { anggota beserta keluarganya. }\end{array}$ \\
\hline & 126 & $\begin{array}{l}\text { (1) Pengusaha, serikat pekerja/serikat buruh dan pekerja/buruh } \\
\text { wajib melaksanakan ketentuan yang ada dalam perjanjian kerja } \\
\text { bersama. } \\
\text { (2) Pengusaha dan serikat pekerja/serikat buruh wajib } \\
\text { memberitahukan isi perjanjian kerja bersama atau perubahannya } \\
\text { kepada seluruh pekerja/ buruh. }\end{array}$ \\
\hline & $\begin{array}{l}136 \\
(1)\end{array}$ & $\begin{array}{l}\text { Penyelesaian perselisihan hubungan industrial wajib dilaksanakan } \\
\text { oleh pengusaha dan pekerja/buruh atau serikat pekerja/serikat buruh } \\
\text { secara musyawarah untuk mufakat. }\end{array}$ \\
\hline & $\begin{array}{l}140 \\
(1)\end{array}$ & $\begin{array}{l}\text { Sekurang-kurangnya dalam waktu } 7 \text { (tujuh) hari kerja sebelum } \\
\text { mogok kerja dilaksanakan, pekerja/buruh dan serikat } \\
\text { pekerja/serikat buruh wajib memberitahukan secara tertulis kepada } \\
\text { pengusaha dan instansi yang bertanggung jawab di bidang } \\
\text { ketenagakerjaan setempat. }\end{array}$ \\
\hline
\end{tabular}

Meskipun dalam perundang-undangan hak karyawan tampak lebih banyak daripada kewajiban karyawan, bukan berarti karyawan tidak wajib menaati aturan perusahaan. Pemberi kerja diperbolehkan membuat peraturan sendiri selama tidak menyalahi UU Ketenagakerjaan. Status tenaga kerja pada sebuah perusahaan bukanlah 'robot' yang tidak memiliki aspirasi atau opini, sehingga Divisi HR memiliki tugas untuk memfasilitasi adanya diskusi dan pembuatan perjanjian kerja yang seimbang antara tenaga kerja dan perusahaan.

tugas yang telah diberikan, ia berhak atas pengupahan yang adil, pemenuhan jaminan sosial, dan waktu istirahat. Pekerja/pun juga berkewajiban membayar pajak penghasilan sesuai aturan yang berlaku. Untuk memudahkan pengelolaan administrasi SDM, sebaiknya Divisi HR menggunakan HRIS seperti Gadjian. Dengan fitur seperti Catatan Absensi, Pola 
Kerja, Penggajian \& THR, hingga Kelola Cuti Karyawan; perusahaan dapat lebih memastikan terpenuhinya hak dan kewajiban pekerja.

Majikan / Pengusaha

\section{Hak dan Kewajiban Pengusaha}

Selain pekerja, pemberi kerja juga wajib untuk memahami aturan yang berlaku pada Undang-undang ketenagakerjaan. Pada dasarnya, Undang-undang Ketenagakerjaan sendiri merupakan aturan baku untuk kedua belah pihak, baik dengan pengusaha maupun karyawan. Dengan mengetahui aturan ini, kemungkinan untuk terjadinya konflik dalam hubungan industrial (antara pekerja dan pemberi kerja) dapat dihindari. Sebenarnya sampai sejauh mana sih hak dan kewajiban pengusaha terhadap pekerjanya berdasarkan peraturan yang berlaku? Berikut ini adalah beberapa hak dan kewajiban pengusaha yang mungkin harus kamu ketahui:

Hak Pengusaha

- Hak atas perlakuan yang hormat dari pekerja

- Berhak melaksanakan tata tertib kerja yang telah dibuat oleh pengusaha

- Hak sepenuhnya atas hasil kerja pekerja

- Berhak atas ditaatinya aturan kerja oleh pekerja, termasuk pemberian sanksi

Kewajiban Pengusaha

- Memberikan ijin kepada pekerja untuk beristirahat dan menjalankan kewajibannya menurut agamanya masing-masing

- Dilarang memperkerjakan pekerja lebih dari 9 jam sehari/melebihi 40 jam seminggu, kecuali ada izin penyimpangan tersebut.

- Tidak boleh mengadakan diskriminasi upah laki/laki dan perempuan

- Bagi perusahaan yang memperkerjakan 25 pekerja atau lebih wajib membuat peraturan perusahaan

- Diwaajibkan membayar upah pekerja pada saat istirahat/libur pada hari libur resmi

- Wajib mengikut sertakan pekerja dalam program BPJS Kesehatan dan BPJS Ketenagakerjaan.

\section{Pendidikan}

1. DefinisiPendidikan

Menurut Undang-UndangNomor 20 Tahun 2003, pendidikan adalah usaha sadar dan terencana untuk mewujudkan suasana belajar dan proses pembelajaran agar peserta didik secara aktif mengembangkan potensi dirinya untuk memiliki kekuatan spiritual keagamaan, pengendalian diri, kepribadian, kecerdasan, akhlak mulia, serta ketrampilan yang diperlukan dirinya, masyarakat, bangsa dan negara.

Pendidikan yaitu tuntunan di dalam hidup tumbuhnya anak-anak. Adapun maksudnya pendidikan yaitu, menuntun segala kekuatan kodrat yang ada pada anakanak itu, agar mereka sebagai manusia dan sebagai anggota masyarakat dapatlah 
mencapai keselamatan dankebahagiaan yang setinggi-tingginya(Siswoyo,2007:19). Dari beberapa pengertian di atas, maka dapat disimpulkan bahwa Pendidikan adalah suatu usaha yang dilakukan secara sadar dan sengaja untuk mengubah tingkah laku manusia, baik secara individu maupun kelompok untuk mendewasakan manusia melalui upaya pengajaran dan pelatihan.

2. Jenjang Pendidikan

Menurut Undang-undang Republik Indonesia No. 20 Tahun 2003 tentang Sistem Pendidikan Nasional Bab VI Pasal 14-19, jenjang pendidikan di Indonesia adalah sebagai berikut :

- Pendidikan Dasar

Pendidikan dasar merupakan jenjang paling dasar pendidikan di Indonesia yang mendasari pendidikanmenengah Anak usia 7 -15 tahun diwajibkan mengikuti pendidikan dasar. Bentuk pendidikan dasar adalah Sekolah Dasar (SD/MI) dan SMP/MTs.

- Pendidikan Menengah

Pendidikan menengah merupakan lanjutan dari jenjang pendidikan dasar.Pendidikan menengah diselenggarakan selama 3 tahun dan terdiri atas Sekolah Menengah Umum dan Sekolah Menengah Kejuruan (SMK).

- Pendidikan Tinggi

Pendidikan tinggi merupakan jenjang pendidikan setelah pendidikan menengah yang mencakup program pendidikan diploma, sarjana, magister, spesialis, dan doktor yang diselenggarakan oleh perguruan tinggi.Pendidikan tinggi diselenggarakan untuk menyiapkan peserta didik menjadi anggota masyarakat yang memiliki kemampuan akademik atau profesional yang dapat menerapkan, mengembangkkan, atau menciptakan ilmu pengetahuan, teknologi atau kesenian

.Jenjang pendidikan tersebut adalah jenjang pendidikan yang secara resmi dan wajib diikuti oleh peserta didik dalam jalur pendidikan formal, tetapi ada tahap pendidikan yang tidak wajib dilaksanakan yaitu pendidikan anak usia dini sebelum mengikuti pendidikan dasar. Pedidikan Anak Usia Dini antara lain adalah Taman Kanak-kanak (TK), dan Raudatful Atfal (RA) yang berada di bawah naungan Departemen Agama

\section{Jam Kerja}

\section{Pengertian Jam Kerja}

Jam Kerja adalah waktu untuk melakukan pekerjaan, dapat dilaksanakan siang hari dan/atau malam hari. Jam Kerja bagi para pekerja di sektor swasta diatur dalam Undang-Undang No.13 tahun 2003 tentang Ketenagakerjaan, khususnya pasal 77 sampai dengan pasal 85. Pasal 77 ayat 1, Undang-Undang No.13/2003 mewajibkan setiap pengusaha untuk melaksanakan ketentuan jam kerja. Ketentuan jam kerja ini telah diatur dalam 2 sistem seperti yang telas disebutkan diatas yaitu:

- 7 jam kerja dalam 1 hari atau 40 jam kerja dalam 1 minggu untuk 6 hari kerja dalam 1minggu; atau 
- 8 jam kerja dalam 1 hari atau 40 jam kerja dalam 1 minggu untuk 5 hari kerja dalam 1 minggu.

Pada kedua sistem jam kerja tersebut juga diberikan batasan jam kerja yaitu 40 (empat puluh) jam dalam 1 (satu) minggu. Apabila melebihi dari ketentuan waktu kerja tersebut, maka waktu kerja biasa dianggap masuk sebagai waktu kerja lembur sehingga pekerja/buruh berhak atas upah lembur. Akan tetapi, ketentuan waktu kerja tersebut tidak berlaku bagi sektor usaha atau pekerjaan tertentu seperti misalnya pekerjaan di pengeboran minyak lepas pantai, sopir angkutan jarak jauh, penerbangan jarak jauh, pekerjaan dikapal (laut), atau penebangan hutan.

Kenaikan tingkat upah berarti penambahan pendapatan. dengan status ekonomi yang lebih tinggi, seseorang akan cenderung untuk meningkatkan konsumsi dan menikmati waktu senggang lebih banyak, yang mengurangi jam kerja (income effect). Di pihak lain kenaikkan tingkat upah juga berarti waktu menjadi lebih mahal

\section{Usia}

Menurut Moekijad (1992:36) menyatakan faktor usia yang dimiliki pekerja sangat berpengaruh sekali dalam menjalankan aktivitas kerjanya, sebagai contoh hal ini bisa kita ketahui pada jenis golongan pelopor. Golongan pelopor usianya antara 25-40 tahun. Golongan pelopor ini memiliki ciri adalah berpikiran maju, pandai, pengetahuan luas, usahanya rata-rata maju, penghasilan tinggi, kaya dan memiliki produktifitas yang tinggi. Sifat keistimewaannya adalah selalu ingin tahu dan aktif menggali pengetahuan sebanyak-banyaknya. Tetapi mereka kurang memperdulikan orang-orang disekitarnya, tidak aktif menyebar luaskan pengetahuan dan pengalamannya. Sedangkan golongan usia tua antara umur 45 tahun hingga 60 tahun ke atas biasanya cenderung statis. Kelompok ini biasanya dimasukan pada golongan penerimaan akhir dan memiliki ciri adalah keadaannya kurang mampu, sifatnya kurang giat untuk hal -hal baru.

Menurut Mulyadi (2003 : 59) tenaga kerja adalah penduduk dalam usia kerja (berusia 15-64 tahun) atau jumlah seluruh penduduk dalam suatu negara yang dapat memproduksi barang dan jasa jika ada permintaanterhadap tenaga mereka, dan jika mereka mau berpartisipasi dalam aktivitas tersebut. Menurut Depnakertrans Tahun 2006 pengertian tenaga kerja ada 2 yaitu,

- Setiap orang yg mampu melakukan pekerjaan guna menghasilkan barang dan jasa baik untuk memenuhi kebutuhan sendiri maupun masyarakat.

$>$ Setiap orang laki -laki atau wanita yang berumur 15 tahun ke atas yang sedang dalam dan atau akan melakukan pekerjaan baik di dalam maupun di luar hubungan kerja guna menghasilkan barang atau jasa untuk memenuhi kebutuhan masyarakat.

Berdasarkan beberapa pendapat di atas dapat disimpulkan bahwa usia pekerja yang produktif yaitu antara 15-40 tahun karena golongan usia tersebut memiliki ciri berpikiran maju, pengetahuan luas serta memiliki sifat ingin tahu yang tinggi, dan sedangkan usia di atas $40-60$ tahun ke atas sudah dikatakan usia tua atau tidak produktif lagi karena usia tersebut cenderung statis. 


\section{METODE PENELITIAN}

Metode penulisan artikel ilmiah ini adalah dengan metode kualitatif dan studi jurnal yang relevan serta Mengkaji Buku-buku sesuai dengan teori yang di bahas khusunya pada hukum tenaga kerja. Disamping itu menganalisis artikel-artikel ilmiah yang bereputasi dan juga artikel ilmiah dari jurnal yang belum bereputasi. Untuk menyesesaikan pokok permasalahan.

\section{HASIL DAN PEMBAHASAN}

\section{Hubungan Pendidikan terhadap Hukum Tenaga Kerja}

Tingkat pendidikan akan mengubah sikap dan cara berpikir ke arah yang lebih baik, dan juga tingkat kesadaran yang tinggi yang akan memberikan kesadaran lebih tinggi seseorang khususnya karyawan serta memudahkan untuk pengembangan diri, dan dengan makin tingginya tingkat pendidikan karyawan tersebut akan mendapat wewenang serta tanggung jawab yang lebih besar dalam suatu perusahaan dimana mereka bekerja.

Menurut Undang-Undang Nomor 20 Tahun 2003, 730endidikan adalah usaha sadar dan terencana untuk mewujudkan suasana belajar dan proses pembelajaran agar peserta didik secara aktif mengembangkan potensi dirinya untuk memiliki kekuatan spiritual keagamaan,pengendalian diri, kepribadian, kecerdasan, akhlak mulia, serta ketrampilan yang diperlukan dirinya, masyarakat, bangsa dan negara.

Seorang pekerja yang berpendidikan tinggi serta memiliki ketrampilan sesuai dengan bidangnya, ia akan mudah mendapatkan pekerjaan karna perusahan banyak memilih pekerja berdasarkan Pendidikan dan keterampilan. Dibandingkan dengan seorang pekerja yang memiliki Pendidikan rendah seperti lulusan SD/SMP yang biasanya memiliki pekerjaan tidak tetap dan bergaji kecil.

\section{Hubungan Jam Kerja terhadap Hukum Tenaga Kerja.}

Jam kerja yang dimiliki setiap pekerja berbeda tergantung dengan perkerjaan yang mereka lakukan. Seperti bekerja disebuah perusahaan yang menetapkan jam kerja dalam 1 hari hanya 7-8 jam dan perminggu 40 jam.

Hal itu tedapat pada undang-undang yang berlaku Kerja bagi para pekerja di sektor swasta diatur dalam Undang-Undang No.13 tahun 2003 tentang Ketenagakerjaan, khususnya pasal 77 sampai dengan pasal 85. Pasal 77 ayat 1, Undang-Undang No.13/2003 mewajibkan setiap pengusaha untuk melaksanakan ketentuan jam kerja. Pada kedua sistem jam kerja tersebut juga diberikan batasan jam kerja yaitu 40 (empat puluh) jam dalam 1 (satu) minggu. Apabila melebihi dari ketentuan waktu kerja tersebut, maka waktu kerja biasa dianggap masuk sebagai waktu kerja lembur sehingga pekerja/buruh berhak atas upah lembur.

Jadi Jam kerja suatu pekerja memiliki hubungan terhadap hukum tenaga kerja yang diamana telah diterangkan pada UU No 13 Tahun 2003. 


\section{Hubungan Usia terhadap Hukum Tenaga Kerja}

Menurut Moekijad (1992:36) menyatakan faktor usia yang dimiliki pekerja sangat berpengaruh sekali dalam menjalankan aktivitas kerjanya, sebagai contoh hal ini bisa kita ketahui pada jenis golongan pelopor. Golongan pelopor usianya antara 25-40 tahun. Dimana hal itu berarti seorang pekerja dikatakan layak untuk mendapatkan pekerjaan jika sudah memasuki usia tersebut. Akan tetapi di Indonesia terdapat hukum tenaga kerja yang mebatasi usia minimal seseorang berkerja.

Negara Republik Indonesia yang berdasarkan Pencasila dan Undang-Undang Dasar 1945 adalah negara hukum yang menjunjung tinggi harkat dan martabat manusia sehingga anak sebagai generasi penerus bangsa wajib memperoleh jaminan perlindungan agar dapat tumbuh dan berkembang secara sehat dan wajar, baik jasmani dan rohani,

Pada UU No 20 Tahun 1999 Pasal 3 ayat 1 yang berbunyi “ Usia Minimum untuk diperbolehkan bekerja di setiap jenis pekerjaan, yang karena sifat atau keadaan lingkungan tempat pekerjaan itu dilakukan dapat membahayakan kesehatan, keselamatan, atau moral orang muda, tidak boleh kurang dari 18 tahun." Yang berarti usia berpengaruh terhadap hukum tenaga kerja, yang dimana seseorang yang belum berusia 18 tahun keatas tidak diperbolehkan berkerja.

\section{Conceptual Framework}

Berdasarkan rumusan masalah penulisan artikel ini dan kajian studi literature review baik dari buku dan artikel yang relevan, maka di perolah rerangka artikel ini seperti di bawah ini.

HUBUNGAN ANTARA HUKUM TENEGA KERJA : PENDIDIKAN,JAM KERJA DAN USIA

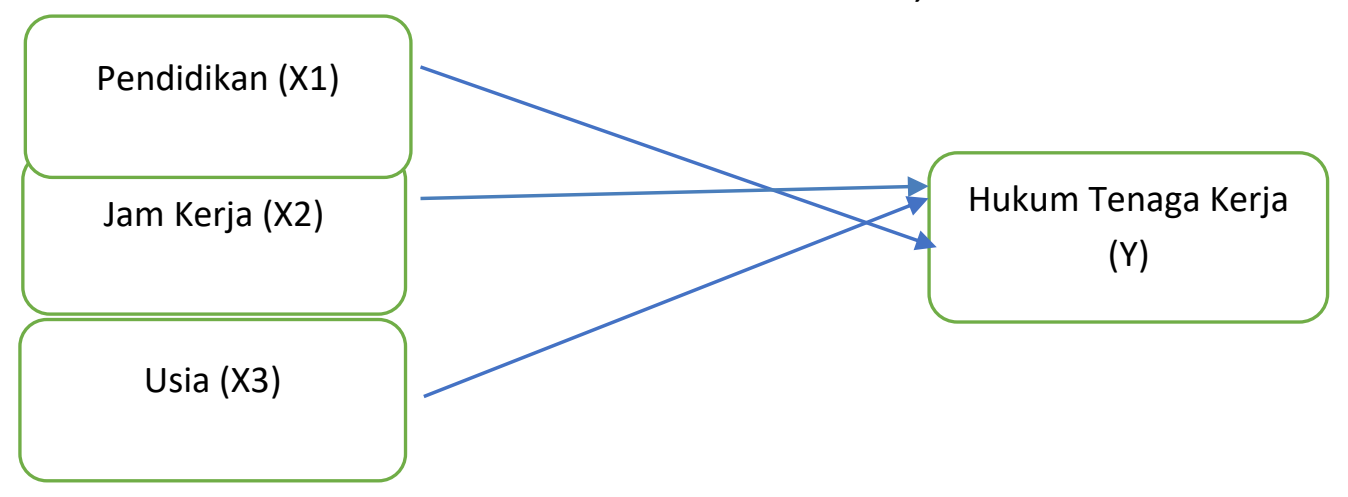

Gambar 1: Conceptual Framework

Berdasarkan Kajian teori dan review hasil dari artikel yang relevan serta gambar dari conceptual framework, maka: Pendidikan,Pengalaman Kerja dan Usia berpengaruh terhadap Hukum Tenaga Kerja.

Selain dari tiga itu yang mempengaruhi Hukum Tenaga Kerja , masih banyak variabel lain yang mempengaruhinya diantaranya adalah:

a) Upah : (Atik Widiastuti,2018)

b) Pengalaman Kerja : (Atik Widiastuti,2018) 


\section{KESIMPULAN DAN SARAN}

\section{Kesimpulan}

Berdasarkan rumusan artikel dan pembahasan maka dapat di di rumuskan hipotesis untuk riset selanjutnya:

1. Pendidikan memiliki hubungan terhadap Hukum Tenega Kerja.

2. Jam kerja memiliki hubungan terhadap Hukum Tenaga Kerja.

3. Usia memiliki hubungan terhadap Hukum Tenaga Kerja.

\section{Saran}

Bersdasarkan Kesimpulan di atas, maka saran pada artikel ini adalah bahwa masih banyak factor lain yang mempengaruhi Hukum Tenaga Kerja, selain dari Pendidikan,Jam Kerja, dan Usia pada semua tipe dan level organisasi atau perusahaan, oleh karena itu masih di perlukan kajian yang lebih lanjut untuk mencari faktor-faktor lain apa saja yang dapat memepengaruhi Hukum Tenaga Kerja selain Pndidikan,Jam kerja dan Usia yang di teliti pada arikel ini. Faktor lain tersebut seperti Upah dan Pengalaman Kerja

\section{DAFTAR RUJUKAN}

Amron \& Taufik Imran.2009. Analisis Faktor-Faktor yang Berpengaruh TerhadapProdutivitasTenagaKerjaPada Outlet Telekomunikasi Seluler Kota Makassar.JurnalSekolah Tinggi Ilmu Ekonomi Nobel Indonesia.

Agus, MT. 1992. Manajemen Sumber Daya Manusia,Jakarta: PT. Gramedia Pustaka Utama. Amstrong, Michael, dan Helen Murlis. 1994. Reward Management Handbook of Remuneration Strategy \& Practice third edition.Engelwood Lift: Prentice -Hall, Inc.

Arfida, BR, MS. 2003. Ekonomi Sumber Daya Manusia.Jakarta: Ghalia Indonesia.

Benita, RA. 2003. Identifikasi Faktor -Faktor yang Mempengaruhi Terhadap Produktivitas Tenaga Kerja sebagai Upaya Peningkatan Pendapatan Nusantara X / Tenaga Kerja Study kasus karyarwan PKWT bag pengolahan PTP persero PG, Toelangan sidoarjo,Skripsi. Fak Ekonomi. Universitas Brawijaya.

Dajan, Anto. 1996. Pengantar Metode Statistik. Jilid 2. Edisi Kedelapan belas. Jakarta: LP3ES. Fakultas Psikologi. 2005. Psikologi Industri dan Organisasi. Universitas Airlangga

Herawati, Nur dan Hadi Sasana. 2013. Analisis Pengaruh Pendidikan, Upah, Pengalaman

Kerja, Jenis Kelamin, dan Umur terhadap Produktivitas Tenaga Kerja Industri Shuttlecock Kota Tegal. Diponegoro Journal of Economics. Volume 2, Nomor 4, halaman 1-8.

Mangkunegara. 2002.Manajemen Sumber Daya Manusia Perusahaan. Cetakan ke empat. Bandung: PT. Remaja Rosdakarya.

Martoyo, Susilo. 1990. Manajemen Sumber Daya Manusia Edisi 2 Cetakan Pertama.Jakarta: Bumi Aksara

Moekijat. 1993. Sistem Akuntansi. Edisi Ketiga. Yogyakarta: BPFE, YKPN.

Mulyadi, S. 2003. Ekonomi Sumber Daya Manusia.Jakarta: Raja Grafindo Persada.

Simanjuntak, J. Payaman.1998.Pengantar Ekonomi Sumber Daya Manusia,, Jakarta: FEUI ( Fakultas Ekonomi Universitas Indonesia)

Todaro, M.P. danSmith, S.C. 2006. Pembangunan Ekonomi. Jilid I Edisi Kesembilan. Haris Munandar (penerjemah). Jakarta: Erlangga. 